Columbia Law School

Scholarship Archive

2012

\title{
Governing Interdependent Financial Systems: Lessons from the Vienna Initiative
}

Katharina Pistor

Columbia Law School, kpisto@law.columbia.edu

Follow this and additional works at: https://scholarship.law.columbia.edu/faculty_scholarship

Part of the Banking and Finance Law Commons, European Law Commons, and the Law and Economics Commons

\section{Recommended Citation}

Katharina Pistor, Governing Interdependent Financial Systems: Lessons from the Vienna Initiative, 2(2) J. GLOBALIZATION \& DEV. Article 4 (2012).

Available at: https://scholarship.law.columbia.edu/faculty_scholarship/2437

This Article is brought to you for free and open access by the Faculty Publications at Scholarship Archive. It has been accepted for inclusion in Faculty Scholarship by an authorized administrator of Scholarship Archive. For more information, please contact scholarshiparchive@law.columbia.edu, rwitt@law.columbia.edu. 


\title{
Journal of Globalization and Development
}

Volume 2, Issue 2 2011

Article 4

\section{Governing Interdependent Financial Systems: Lessons from the Vienna Initiative}

\author{
Katharina Pistor, Columbia Law School
}

\section{Recommended Citation:}

Pistor, Katharina (2011) "Governing Interdependent Financial Systems: Lessons from the Vienna Initiative," Journal of Globalization and Development: Vol. 2: Iss. 2, Article 4. 


\title{
Governing Interdependent Financial Systems: Lessons from the Vienna Initiative
}

\author{
Katharina Pistor
}

\begin{abstract}
Financial markets have become globally interdependent, yet their governance has remained national at the core. This friction encumbers crisis management and distorts incentives for crisis prevention. The Vienna Initiative, formed to manage the fallout from the global crisis in the countries of Central and Eastern Europe (CEE), offers an alternative coordinated, multi-stakeholder governance framework. A critical prerequisite for such a regime is a coordinating agent, or 'anchor tenant', that is deeply vested in the stability of transnational financial systems, but does not directly compete with market actors or regulators. Lessons for more effective governance of financial interdependence are discussed.
\end{abstract}

KEYWORDS: global finance, global governance, bank regulation, fiscal responsibility

Author Notes: Katharina Pistor is the Michael I. Sovern Professor of Law, Columbia Law School. I would like to thank two of the architects of the Vienna Initiative, Erik Berglöf and Piroska Nagy at the EBRD, for their generous sharing of information and their comments on suggestions. In addition, I would like to thank participants at the Comparative Law and Economics Forum 2010 held at Yale, as well as those at the Conference on Contract Governance in Berlin in October 2010 and two anonymous reviewers for helpful comments and suggestions. All remaining errors are mine. 
Pistor: Governing Interdependent Financial Systems

\section{Introduction}

The liberalization of financial markets has given rise to a complex and highly interdependent financial system where events in one of its parts can easily spread to others and threaten the entire system. The global financial crisis with its origins in the US subprime mortgage market has demonstrated the scale and scope of financial interdependence worldwide. It is particularly pronounced in Europe with its legally enshrined commitments to the free flow of capital and financial services. The transformation of the former socialist countries and the accession of many countries from Central and Eastern Europe (CEE) to the European Union provided opportunities for banks from the West to expand eastwards and build pan-European financial groups.

The emergence of a complex, interdependent, transnational financial system notwithstanding, the governance of finance has continued to be national at its core. Regulatory and supervisory standards have been harmonized across countries; supervisory powers have been divided between home and host countries; ${ }^{1}$ yet, lender of last resort responsibility has remained national (Goodhart and Schoenmaker, 2006). Even at the global level fiscal responsibilities are delineated nationally. The International Monetary Fund (IMF) may be international in the manner in which it pools resources and establishes governance standards, but is strictly bilateral when it comes to the allocation of these resources and the conditioning of their use.

This paper argues that the primacy of national governance over transnational finance constrains and distorts ex ante governance and ex post crisis management. It explores alternative governance regimes that are compatible, in principle, with fiscal sovereignty of nation states but take account of increasing financial interdependencies. The paper applies these theoretical considerations to an emergent transnational governance regime, the Vienna Initiative, which was created in the midst of the global crisis to prevent a financial meltdown in CEE. This initiative has evolved from an ad hoc crisis management system into a forum for deliberating general governance issues for transnational financial markets under the label "Vienna Plus".

This paper suggests that the Vienna Initiative displays critical elements for governing interdependent financial systems: coordinated, multi-stakeholder governance facilitated by an international agent in the role of anchor tenant (Powell, 2010) - an agent that is deeply vested in the stability of transnational financial systems, but does not directly compete with market actors or regulators. In the initial phase of the Vienna Initiative, the European Bank for Reconstruction

\footnotetext{
${ }^{1}$ The De Larosière Report (2009) commissioned by the EU in the aftermath of the Global Crisis recommends the use of Colleges of Supervisors for all major transnational financial institutions in the EU.
} 
and Development (EBRD) has performed this role, with the EU Commission and the IMF evolving into co-anchors as the initiative has deepened.

\section{Governance Challenges of Interdependent Financial Markets}

Financial markets have been at the forefront of globalization. Capital account liberalization and the high levels of capital mobility have linked financial markets around the globe. The scale of financial integration as measured by the ratio of stock of external assets (liabilities) to GDP has increased from only 7 percent on average in the early 1970s to 300 percent in 2004 (Lane and Milesi-Ferritti, 2007).

The same transnational links that made possible the globalization of finance, i.e. transnational lending channels, portfolio investments and foreign direct investment, also served as transmitters of the crisis (Cetorelli and Goldberg, 2011). Not all economies were affected at the same time or in the same manner. The crisis began in the US and the UK, and from there spread to Western Europe and affected emerging markets in Asia, Central and Eastern Europe (IMF, 2009). The lag effect and the varying severity of the crisis experienced by different countries and regions suggests that, globalization notwithstanding, a fully integrated global markets does not yet exist. At the same time, the inability of individual countries to decouple from the cascading effects of the global crisis is indicative of deep interdependencies between financial systems that crisscross national economic systems. For the purpose of this paper we therefore define financial interdependence as a level of financial integration that makes it impossible to decouple in the event of a crisis, yet lacks a centralized governance structure.

Transnational contagion effects had manifested themselves in earlier banking crises (Kapstein, 1996). They triggered efforts under the auspices of the Bank for International Settlement (BIS) to harmonize basic principles of prudential regulation for transnational banks and to coordinate their supervision. The Basel Accord, spearheaded by the Basel Committee on Banking and Supervision, developed prudential principles for bank regulation, including capital adequacy rules. The Basel Concordat established a division of labor between home and host country regulators based on the place of incorporation and licensure of transnational banks: Regulators of parent banks are responsible for consolidated supervision of the parent bank and its overseas branches; regulators in countries where subsidiaries are incorporated are charged with acting as their home country regulators. Tied to this division of labor is the home country's 
responsibility to provide liquidity and systemic risk management in the event of distress. $^{2}$

The formal distinction between subsidiaries and branches on which this model is based assumes that de-stabilizing events are local and that de-coupling is feasible. Yet, the events of the global crisis have demonstrated that the fate of subsidiaries is closely intertwined with that of their parent banks. Parent banks that were caught in the crisis withdrew capital not only from their foreign branches, but also from their foreign subsidiaries (Cetorelli and Goldberg, 2011; De Haas, et al., 2011). In countries with high concentrations of foreign owned subsidiaries this reverse supply shock threatened the stability of the domestic financial system.

The deepening integration of transnational bank groups would have warranted much closer coordination between parent and subsidiary regulators, but this was seriously wanting (Herring, 2007; Kapstein, 2006). Memoranda of understanding (MoUs) between parent and subsidiary regulators to ensure information sharing and effective supervision were signed, but rarely put into action. Moreover, they focused on providing parent bank regulators with relevant information about subsidiaries, but less on ensuring that regulators of subsidiaries had sufficient information about parent banks and the risk a reversal of their fortunes might pose for their countries. In a world of financial interdependencies where a crisis in a far away country can quickly spread throughout the system and reach every market, such a fragmented governance structure can easily backfire and the global crisis demonstrated that it would.

Interdependencies between financial systems are particularly pronounced between Western and Eastern Europe. Banks located in Western Europe took advantage of the liberalization of financial markets in the former socialist countries to the East and the accession of many CEE countries to the European Union and expanded eastwards. They acquired formerly state owned banks and channeled credits to the region either through their web of subsidiaries or by lending directly across borders - and in foreign currency, thereby adding currency risk to the lending risk (Pann, et al., 2010). As of 2007, foreign bank groups mostly from Austria, Sweden, Italy, France, Germany and Greece - controlled on average 70 percent of bank assets (ECB, 2005), between 36 (Slovenia) and 98 (Estonia) percent throughout the region (Enoch, 2007). ${ }^{3}$ The parent banks of these

2 The same division of labor has become part of the EU governance regime for financial intermediaries with the additional element of the European passport system. See Art. 23 of DIRECTIVE 2006/48/EC OF THE EUROPEAN PARLIAMENT AND OF THE COUNCIL of 14 June 2006 relating to the taking up and pursuit of the business of credit institutions (recast), OJ L177/1, 30 June 2006.

${ }^{3}$ See also (Dinger, 2009) who reports for 2004 the share of foreign-owned banks as between 23 percent in Slovenia and 99 percent in Estonia, with Poland having a share of 60, Hungary 65, and the Czech Republic 90 percent. 
transnational banks used their access to transnational inter-bank lending markets to fuel the expansion of credit in Eastern Europe, which reached annual growth rates of over 30 percent in several countries prior to the crisis (Arcalean, et al., 2007; De Haas, Korniyenko, Loukoianova and Pivovarsky, 2011). When interbank lending markets collapsed after the bankruptcy of Lehman Brothers, funding dried up and parent banks began to withdraw capital from the region - an estimated US $\$ 57$ bln by early $2009{ }^{4}$

Available crisis responses consisted of well-established national, bilateral, and supranational strategies. National response strategies dominated in the major European economies after the collapse of Lehman Brothers. Country after country protected its domestic financial system from collapse by offering lender and investor of last resort (LLR) facilities without much regard for how this would affect other countries (IMF, 2009). ${ }^{5}$ Countries in CEE could not afford similar bailout packages and turned to the IMF for help. The IMF concluded standby agreements with Ukraine and Latvia in the fall of 2008 and with Hungary and Bosnia-Herzegovina in early 2009. In addition, it created flexible credit lines with Poland and Moldova, both in 2009 (IMF, 2011). In line with the IMF's established practice, these agreements were bilateral and did not involve countries that were the home of transnational bank groups with substantial exposure to the countries now requiring assistance.

The fact that most of the affected countries in the East had already become members of the European Union or were prospective member states should have facilitated a more coordinated response strategy. ${ }^{6}$ The EU has a wellinstitutionalized governance regime for transnational financial markets consisting of a multi-tier process for harmonizing regulatory and supervisory standards for financial intermediaries in all EU member states (Lamfalussy, 2001; Vander Stichele, 2008). EU directives and regulations establish the general policy framework with detailed technical regulation being left to committees that specialize in different financial services, such as securities, insurance, and banking. The Committee of European Banking Supervisors (CEBS) was in charge of implementing and refining banking regulation. It convened representatives of regulators and supervisors from all member states, consulted with the regulated industries, and issued guidelines for the implementation of EU directives and regulations. This should have enabled CEBS to play a critical role in coordinating the response to the financial crisis in CEE; yet, it remained largely passive. This is

\footnotetext{
4 Nagy, P. (2009) 'BIS Data on Cross-Border Flows: A Closer Look', EBRD Blog, 11 May, available at: www.ebrdblog.com/2009/05/11/bis-data-on-cross-border-flows-a-closer-look/. (last visited 3 June 2011).

5 According to the IMF, countries that bailed out their domestic financial systems created a safe haven for investors, who now began fleeing from emerging markets (IMF, 2009).

${ }^{6}$ These countries include Croatia, Serbia, and Bosnia-Herzegovina (not, however, Ukraine).
} 
not as surprising as it might seem: The threat of financial collapse required LLR facility, i.e. a fiscal response - not more coordination in the regulation and supervision of financial intermediaries. Yet, neither CEBS nor any other entity in the EU has fiscal authority, which remains firmly vested with the EU's individual member states. ${ }^{7}$

Despite these institutional constraints Hungary openly sought a common European rescue package for the region, but was turned down. ${ }^{8}$ Countries with banking systems that were exposed to CEE did not push for a European solution either. Instead, they hoped that the worse afflicted countries would receive help from the IMF, and that this would mitigate the effects of a crisis in CEE on their home systems. ${ }^{9}$ IMF assistance was indeed forthcoming, but did little to stem the threat of contagion. This threat was ultimately avoided by a "novel European private-public coordination platform" (EBRD, et al., 2011), commonly referred to as the Vienna Initiative.

\section{Theoretical Perspectives on Governing Interdependence}

Financial interdependence demands more of a governance regime than ex ante rulemaking and consistent rule implementation. Because interdependence makes de-coupling prohibitively costly if not impossible, cooperation in ex post crisis management is critical to avoid a contagious meltdown. Rulemaking and rule implementation would be sufficient under the assumptions that markets don't change, that regulators can identify optimal rules ex ante, and that it is possible to effectively implement such rules in all parts of an interdependent financial system. These are highly unrealistic assumptions. First, change, uncertainty and crises have been a hallmark of financial markets since their inception (Kindelberger, 2005; Reinhart and Rogoff, 2009). If anything, technological change and financial innovation have accelerated in recent decades, making the task of identifying and implementing appropriate regulatory goals all the more

\footnotetext{
${ }^{7}$ A partial exception is the European Financial Stability Facility (EFSF), which was created as a temporary device in May 2010 in the context of the deepening crisis in Greece. However, it does not offer support to non-governmental entities, such as banks. For details, see Art. 3 of the EFSF's Articles of Incorporation, available at http://www.efsf.europa.eu/about/legal-documents/index.htm (last visited 4 June 2011). The EFSF is to be replaced by a permanent European Stability Mechanism in 2013. See "Term Sheet of the ESM", Annex II to the Conclusion of the European Council Meeting, 24/25 March 2011, available at http://www.european-council.europa.eu/councilmeetings/conclusions.aspx?lang=en (last visited 4 June 2011).

8 "Ailing in the East: European Union leaders decline to bail out Eastern Europe", The Economist, 1 March 2009, available at www.economist.com (last visited 15 March 2011).

${ }^{9}$ In its financial stability report of June 2009 the Austrian central bank stated with some relief that 'in light of recent rescue measure by the IMF and the EU Commission, extreme scenarios have become much less likely’ (ONB, 2009).
} 
difficult, and adding complexity and fragility to the system. Second, even the best intentioned and well informed rule maker cannot possibly anticipate all future contingencies that might require regulatory intervention, as law and regulations are inherently incomplete (Pistor and $\mathrm{Xu}, 2003$ ). Third, the harmonization of laws and regulations is typically the result of compromises that deviate from optimal rules. The history of the Basel Accord suggests that politics, not optimal rulemaking, has guided much of the process from the original setting of the capital adequacy rule in Basel I (Kapstein, 1996; Simmons, 2001) to the internal risk management models in Basel II (Claessens, et al., 2008; Danielsson, et al., 2001). The same dynamic afflicts attempts to develop international resolution mechanisms for transnational banks (Howcroft, 2008) and sovereign debt workouts (Gelpern, 2004).

Nonetheless, most efforts at governing the transnational financial system continue to focus on rulemaking and rule implementation. Dealing with crossborder bank insolvencies has proved politically intractable, leaving any attempt to address cross-border fiscal responsibilities beyond reach. A sustainable interdependent financial system, however, requires a credible crisis resolution regime and must ensure that the ex ante allocation of regulatory responsibilities is aligned with such a regime. Instead, accountability for regulatory failure stops at the border and the effects of contagion are borne by countries where they manifest themselves. Only in few instances has the IMF been able to ensure private sector involvement, and typically only when the crisis had deepened sufficiently to force its hand - and that of the banks (Roubini, 2001). There is even less evidence that the IMF has ever insisted on burden sharing by home regulators of banks whose foreign operations were implicated in a crisis, or convened all critical stakeholders of interdependent financial markets that were implicated by a crisis. ${ }^{10}$ Instead, the IMF has tended to treat financial market crises as domestic affairs of individual countries. Weak institutions, not flaws in the governance of interdependent financial markets, have been held responsible for transnational crises. ${ }^{11}$

This approach is exemplified in "International Financial Architecture", the IMF's answer to the East Asian financial crisis. It advocates the streamlining of rules and regulations that pertain to finance around the globe based on best practice standards derived from leading market economies, most prominent among them the US and the UK (Fratianni and Pattison, 2002; IMF, 2003; Pistor,

\footnotetext{
${ }^{10}$ While the US intervened in the Tequila crisis that beset Mexico in 1994, there is no evidence that the IMF induced this assistance. To the contrary, press reports point to potential conflicts of interests by then Treasury Secretary Paul Rubin, who used a discretionary Treasury account to offer US $\$ 20$ bln bailout assistance, which allegedly benefited his former employer, Goldman Sachs. See Keith Bradsher, "House votes to Request Clinton Data on Mexico", The New York Times, 2 March 1995, available at www.NYTimes.com (last visited 3 June 2011).

${ }^{11}$ This approach may be changing inside the IMF. For a more positive assessment of the learning ability of this institution, see (Lütz and Kranke, 2010).
} 
2002). There is some irony in the fact that the very countries that served as models for the international financial architecture designed to address the last global crisis found themselves at the very heart of the next one. More importantly for the argument developed in this paper, the IMF's approach to governing interdependent financial markets remains focused on domestic, ex ante regulation. Financial sector assessment programs (FSAPs) have been conducted on a countryby-country basis, and reforms targeted at domestic legal and regulatory institutions. The gaping hole in the governance of financial interdependencies the absence of ex post crisis resolution, including LLR facilities - has not been addressed. $^{12}$

The same is true for the governance of finance in the EU. The global financial crisis exposed the lack of a workable governance framework for interdependent finance. Not surprisingly, the immediate crisis response became a national affair. ${ }^{13}$ There is a more positive account of European governance in the literature, which asserts that experimental, multi-stakeholder governance has become a hallmark of EU governance. According to this account, formal EU bodies develop broad principles of coordinated governance, with the fine-tuning and implementation being left to multiple stakeholders in a process that amounts to "direct, deliberative polyarchy" (DDP) (Sabel and Zeitlin, 2008). Sabel and Zeitlin list the Lamfalussy process for governing European financial markets as one such example. However, the Lamfalussy process has been far less democratic and deliberative than they envisioned and instead was affected by the "possible domination by large states/producer interests" (ibid at 297). The interests of home and host countries within CEBS were not well balanced (Pistor, 2010); most of the relevant financial service directives were promulgated before the accession of new member states that became important destinations for trans-European capital flows. While the new member states nominally had a voice in CEBS, they were not in the inner circle of country representatives with long-established relations. Private actors were consulted and commented on draft guidelines issued by CEBS, such as the home-host guidelines, but here again the well-established financial industry from the old member states dominated (Pistor, 2011).

A common response to the shortcomings of transnational governance that has to rely ultimately on national enforcement institutions is the establishment of a supranational agent. Leaving aside the political feasibility of such a move, it is questionable on theoretical grounds whether a single centralized institution is an appropriate solution for governing financial interdependence. Several arguments

\footnotetext{
12 While the possibility of a bankruptcy regime for sovereign debt has been discussed (see (Krueger, 2002)), these discussions have not extended to private credit resolutions.

${ }^{13}$ While the EU later scrutinized these bailout packages under its state-aid principles, these principles did not prevent individual governments from coming to the aid of its financial sector in the midst of the crisis. See (Dewatripont, et al., 2010) and (Pisani-Ferry and Sapir, 2010).
} 
speak against this. First, centralized governance based on hierarchical structures of authority (Coase, 1937) is not very conducive for governing systems that are characterized by uncertainty and unpredictability (Minsky, 1986). Organizational theory has shown that traditional unitary, or U-Form organizations with a hierarchical monitoring and governance apparatus are well positioned for implementing strategies for knowable and controllable outcomes; however, they tend to impede innovation. In contrast, decentralized organizations that divide management responsibilities among multiple functional departments (M-Forms) are more likely to offer flexible solutions under conditions of uncertainty and are more conducive to innovation (Qian, et al., 2006; Williamson, 1975).

Furthermore, the internal governance structure of classic centralized agents is not well attuned for governing interdependencies. The IMF is the most likely organization to assume such a role. Its internal governance structure has been much debated and only gradually and reluctantly reformed. ${ }^{14}$ The major critique is that it is undemocratic, beholden to the immediate post WWII geopolitical order that no longer exists (Tan, 2006; Woods, 2006), and captured by the financial industry (Mattli and Woods, 2009). While this may well be true, it is not clear that equal voting rights or their weighing by population would make the IMF a better agent of interdependent financial markets. The global financial system does not affect all countries in the same manner, and the size of its population may not be the best indicator for determining a country's risk exposure to global finance. More relevant is whether a country is the home of major transnational banks, or a destination market for the financial services they provide. This is what determines their regulatory sovereignty or exposure to the efficacy of other countries' regulators. Another important factor is whether a country has sufficient resources or borrowing capacity to function as LLR in the event of a crisis, or will require IMF assistance. Neither is it apparent that changes in the voting arrangement of the IMF would necessarily weaken the power of the financial industry, which, as a result of financial liberalization has become sufficiently mobile to survive changes in the political bargaining power of their current home states.

Comparisons with the arguably more democratic governance structure within the EU highlight that democratic governance does not assure effective governance of interdependencies. All EU member states were represented at CEBS, which worked by consensus, or votes weighed by population in the event consensus could not be reached. However, these arrangements did not protect the Baltic countries from aggressive expansion strategies by Swedish banks, or address the risk of CEE countries to Austrian banks, which controlled on average 20 percent of the market share throughout the region (ONB, 2009).

\footnotetext{
${ }^{14}$ For the latest reform of voting rights at the IMF see http://www.imf.org/external/np/sec/memdir/eds.aspx (last visited 13 June 2011).
} 
Giving all countries within a regional or global club equal voice in governance and crisis resolution would arguably be both over- and underinclusive: Over-inclusive because not all countries are equally interdependent with one another; under-inclusive because financial systems are not bounded by the territory of the EU. Thus, UK banks were more closely intertwined with Irish than with CEE markets; Spanish banks had expanded in Latin America, but, at least prior to the crisis, ${ }^{15}$ hardly in Eastern Europe; and Austrian banks had developed financial markets not only in new EU members states, such as Hungary and the Czech Republic, but also in non-members like Croatia, Ukraine and Russia.

The new EU regime that was adopted after the crisis incorporates many of the old regime's defects. At least on paper, the reform package sought to strengthen the EU's hand in regulating financial markets by elevating them from 'committees' to 'authorities' 16 and giving them a new internal governance structure with a chairman and board. ${ }^{17}$ At the same time, the reforms explicitly confirmed national sovereignty in fiscal affairs by including a provision that states that the new European System of Financial Regulators shall not take any action that might impinge on the fiscal sovereignty of the EU's member states. ${ }^{18}$

A more promising solution to the challenges of governing financial interdependence is coordinated governance. Such a governance regime would not be territorially bounded, but open-ended to reflect the actual scale and scope of interdependent financial markets. All regulators and fiscal authorities from countries that partake in these markets, whether as host or home countries, as well as financial intermediaries, would participate in this regime. An open question is how such a networked structure would be created and maintained. Networks are not uncommon in the governance of international relations (Ruggie, 2004), with the G7, the G8, and now the G20 being only the most visible among them (Payne, 2010). However, self-organized networks resemble clubs whose members share certain common interests and protect them through entry barriers. In contrast, governing interdependent financial markets requires coordination among stakeholders with conflicting interests. Bringing together diverse stakeholders can greatly enhance the prospects of finding innovative solutions for new challenges (Burt, 1995; Powell, 1990). However, self-organization is less likely given the

\footnotetext{
15 They did, however, acquire several banks during the crisis. See EBRD, EIB and World Bank Group (2011).

16 The Committee for European Bank Supervisors (CEBS), for example, was reincarnated as the European Banking Authority (EBA).

${ }^{17}$ See Arts. 6, 43, 47, 48, 53 of Directive 2010/78/EU, op. cit. at 26.

18 See specifically the REGULATION (EU) No 1093/2010 OF THE EUROPEAN PARLIAMENT AND OF THE COUNCIL of 24 November 2010 establishing a European Supervisory Authority (European Banking Authority), establishing in recital 5 that new European supervisors should not "impinge on the fiscal responsibilities of Member States".
} 
divergent interests. Sometimes a crisis can bring about a new configuration of previously adverse stakeholders (Padgett and McLean, 2006). Alternatively, an agent with convening power vis-à-vis all relevant stakeholders can accomplish this. Such an agent has been dubbed an "anchor tenant"19 (Powell, 2010):

"The anchor tenant is not disinterested, in the sense of being neutral, but is not directly competitive with the other types of organizations that inhabit the community. [They] (...) occupy positions that provide them with access to diverse participants and the legitimacy to engage with and enroll others in ways that facilitate the extension of collective resources. This ability to span disparate domains has proven valuable in high-velocity environments where resources, power, and wealth are constantly shifting (ibid at 71)."

The demands on such an agent are markedly different from the functions the IMF has played in crisis management. Rather than seeking to stabilize an individual country, the anchor tenant would target the system. Not only a country in crisis, but all relevant stakeholders in the interdependent system, whether public or private, domestic or foreign, markets already in crisis or those being exposed to channels that might transmit the crisis, would be involved in the governance regime. Ideally, such a regime would operate not only as a crisis management system, but also to prevent crises. The critical institutional design problem for such a regime is the identification of an agent that is capable of performing the role of anchor tenant. The following discussion of the Vienna Initiative will demonstrate that a regime with the features just outlined is feasible and that it is possible to identify important characteristics of prospective anchor tenants.

\section{The Vienna Initiative}

When the global crisis reached CEE, the stakeholders in the interdependent financial system that spanned the European continent were stuck in a classic prisoner's dilemma. Each faced incentives to protect its immediate interests, but doing so was likely to trigger the collapse of the financial system in CEE, and possibly beyond.

At the outset of the crisis Western European banking groups that had expanded into CEE appeared to be sufficiently diversified to survive a shock in one part of the system without having to scale back their operations considerably

${ }^{19}$ Literally, the term 'anchor tenant' refers to a critical tenant in a newly established shopping center, one that is capable of attracting other tenants as well as customers. See, for example, (Gatzlaff, et al., 1994). 
(ONB, 2009). Empirical evidence suggests that transnational financial groups tend to cross-subsidize subsidiaries in domestic downturns to stabilize the group (De Haas and Van Lelyveld, 2010). Pan-European bank groups did just that in 2007 and the beginning of 2008, which explains why the financial systems in the $\mathrm{CEE}$ region remained fairly stable during the early period of the crisis (Berglöf, et al., 2009). This changed, however, when the parent banks themselves were caught in the global financial downturn. They were now confronting the need to recapitalize core operations and began to withdraw capital from the periphery.

The parents' home country regulators re-enforced the impetus to concentrate on the core. As the financial crisis deepened, several parent banks received a bailout from their home country authorities, which came with the explicit or implicit condition that they be used exclusively for domestic banks (Pisani-Ferry and Sapir, 2010). ${ }^{20}$ Regulators in CEE countries with a strong presence of foreign bank subsidiaries responded to the threat of a reverse capital flow by taking defensive measures. Most had initially welcomed the rapid expansion of credit markets facilitated by foreign capital flows. ${ }^{21}$ Still, some had tried to stem the flow of credit as they grew fearful of a credit bust (Arcalean, Calvo-Gonzales, More, Rixtel, Winkler and Zumer, 2007). The countermeasures they took, such as increasing reserve requirements or imposing credit ceilings on banks within their jurisdiction, proved largely unsuccessful (Bednarski and Starnowski, 2007; Hilbers, et al., 2007). Foreign bank groups could easily sidestep them by lending directly to customers in other member states, ${ }^{22}$ or by channeling capital through unregulated financial intermediaries. ${ }^{23}$ Against this background host countries sought to disavow legal obligations enshrined in the home-host division of labor to insure the deposits of foreign subsidiaries or to provide them with liquidity. Some even threatened to ring-fence assets of bank subsidiaries as capital was leaving their countries (Popov and Udell, 2010). ${ }^{24}$

\footnotetext{
${ }^{20}$ Austria limited its bailout facility to financial institutions regulated under its banking legislation, which includes branches of Austrian banks in other countries, but not their subsidiaries. See Sec. 1 "Finanzmarktstabilitätsgesetz"(financial market stabilization law) available at http://www.fmarktbet.at/cms/cms.php?pageName=73 (last visited 4 June 2011).

${ }^{21}$ Note that prior to the crisis credit growth for foreign owned banks tended to be higher in most countries in the region than in state owned or domestic banks. See (De Haas, Korniyenko, Loukoianova and Pivovarsky, 2011) Table 1.

${ }^{22}$ This practice was based on the principle of free movement of capital enshrined in the Treaty and further endorsed by the "European Passport System", which allows banks that were authorized by one member state to offer financial services throughout the European Union. For details see (Pistor, 2011).

${ }^{23}$ The Austrian National Bank investigated the lending practices of Austrian banks in 2009 and reported that many used leasing companies and direct lending to continue credit expansion in countries where restrictions were imposed on their subsidiaries. See (ONB, 2009).

${ }^{24}$ Popov and Udell (2010) document that foreign bank subsidiaries were more likely to curtail credits and reduce their capital than domestic banks.
} 
Home countries, for their part, were mostly concerned with rescuing their domestic financial system, not with system-wide effects.

The European Central Bank (ECB) saw the crisis in CEE unfolding, but was institutionally constrained. The ECB's mandate is restricted to maintaining price stability ${ }^{25}$ and to countries that belong to the Eurozone. Yet, many countries that were afflicted by the crisis in CEE had not adopted the euro. Sweden, whose banks had expanded aggressively in the Baltics where they controlled over one third of total foreign bank funding, ${ }^{26}$ is not part of the Eurozone. Of the new member states that were at the center of the financial storm, only Slovenia had already adopted the euro (in 2007), with Slovakia following in 2009. Still, as the crisis deepened, the ECB offered euro liquidity to the central banks of Denmark, Sweden, Poland and Hungary. Unlike the US Federal Reserve, however, the ECB required Euro denominated collateral from countries that were not part of the Eurozone (Moessner and Allen, 2010), thereby limiting the measure's effect. ${ }^{27}$

The Vienna Initiative emerged in this context. The heads of several bank groups with a strong presence in CEE wrote a letter to the European Commission (EC) that was copied to the European Investment Bank (EIB) and the EBRD. ${ }^{28}$ The letter sought to put pressure on CEE countries to grant liquidity support to local subsidiaries. By calling simultaneously on the EC, the EIB and the EBRD, the banks were exposing the governance vacuum at the heart of the pan-European financial system: the lack of an ultimate guardian for the interdependent, panEuropean financial system (Pistor, 2011).

The banks' call notwithstanding, the EC stayed on the sideline as it had throughout the earlier stages of crisis, when member states took their fate into their own hands and bailed out their domestic banks. Of the supranational organizations addressed in the letter, the EBRD was the only one that responded immediately. In collaboration with the Austrian Ministry of Finance it organized

\footnotetext{
${ }^{25}$ See Art. 2 of the Protocol No. 4 on the Statute of the European System of Central Banks and of the European Central Bank, OJ C115/230, last amended 9 May 2008. Available at http://www.ecb.int/ecb/legal/1341/1343/html/index.en.html (last visited 13 June 2011).

${ }^{26}$ Robert Anderson, "Baltic Risk to Swedish Banks", The Financial Times, 12 August, 2008, available at www.ft.com (last visited 3 June 2011).

${ }^{27}$ These measures fell well short of those taken by the US Federal Reserve (Fed), which extended liquidity provisions for selected countries around the world, accepting local currencies as collateral. See Board of Governors of the Federal Reserve System of the US (Fed), Press Release 29 October 2008, available at http://www.federalreserve.gov/newsevents/press/monetary/20081029b.htm (last visited 15 March 2011).

${ }^{28}$ Stefan Wagstyl, "Banks ask for crisis funds for eastern Europe", The Financial Times, 21 January 2009, available at www.ft.com (last visited 25 May 2011). The banks involved in the initiative were Raiffeisen and Erste Bank (Austria); Unicredit and Intessa Sanpaolo (Italy); Societe General (France); KBC (Belgium); Bayerische Landesbank (Germany); Swedbank (Sweden); SEB and EFG Eurobank (Greece).
} 
several brainstorming sessions, each initially devoted to a single group of stakeholders (banks, ministers of finance, regulators). It cooperated with the World Bank Group and the EIB to provide resources to pan-European bank groups to prevent a major capital retrenchment in the CEE host countries. This "Joint IFI Action Plan", "In Support of Banking Systems and Lending to the Real Economy in Central and Eastern Europe", initially mobilized €24.5 bln and ultimately disbursed $€ 33$ bln (EBRD, EIB and WorldBank, 2011). The plan signaled the commitment by IFIs to tackle the crisis as a regional crisis rather than several distinct national ones and came at a critical moment when conditions in Romania and Serbia were deteriorating, threatening contagion throughout the region (Nitsche, 2010). Thus, IFI funding provided a critical component in the total amounts made available. National bailout funds and their extension to foreign subsidiaries, bank rollovers, and IFI funding each on its own would have been insufficient to stabilize the region, but the combined effort achieved this goal. $^{29}$

The stakeholder meetings and additional meetings organized jointly with the IMF in countries most affected by the crisis culminated in a joint meeting in Vienna in March of 2009 at which all relevant public sector stakeholders were present: finance ministries, regulators and central banks from host and home countries, IFIs (the World Bank, the IMF and the EBRD), the EC, and the ECB as observer. After a day of discussions in which each group of stakeholders was able to voice its needs and demands on others, the following commitments were made:

- Host countries committed to conduct reasonable macroeconomic policies in accordance with IFI agreements, to provide liquidity and deposit insurance to subsidiaries of foreign bank groups, and not to ring-fence assets;

- Home countries agreed to make bailout money available to bank groups without constraining where these resources were used;

- IFIs offered funding to pan-European bank groups, to stand by individual countries, and to stay engaged in monitoring regional developments.

- At subsequent country-specific meetings, ${ }^{30}$ bank groups committed in writing not to disengage from CEE, to maintain the financial health of

\footnotetext{
${ }^{29}$ I am grateful to an anonymous reviewer for pointing out the interdependence of these funding sources.

${ }^{30}$ Note that at subsequent full Vienna Initiative meetings, banks participated directly. This is also reflected in the new name attributed to it: "The European Bank Coordination Initiative".
} 
their subsidiaries, to consent to stress tests conducted by the IMF, and to make their commitments public. ${ }^{31}$

Each of these commitments went well beyond the narrow self-interest that had characterized the immediate and primarily national responses to the crisis in other countries. This was made possible because they were reciprocated in an open forum by commitments from other stakeholders. As one participant of the meeting observed, the open forum where all stakeholders had a voice induced each one to offer more than they individually had been willing to give: "It pushed them to their limits". 32

None of the commitments were legally binding, nor were sanctions announced for defectors. Neither was the meeting simply a venue for a mediation process. Mediation entails splitting differences typically in a situation where litigation remains a fallback option, or where one party might walk away from the deal unless a reasonable solution is found. In contrast, the Vienna Initiative created ground rules that facilitated extensive coordination among all stakeholders that had to contribute to stabilize the system. These ground rules included an agreement to agree; open deliberations; and publicity about commitments made. ${ }^{33}$

Between March and June 2009 a series of meetings followed that focused on individual countries one at a time. They identified specific financial and regulatory needs of a country or bank group and defined the commitments made by the IMF and other multilateral lending organizations. Following the procedural rules established by the Vienna Initiative, at each of these meetings parent banks signed commitment letters for the countries in question and these commitments were made public (Nitsche, 2010). ${ }^{34}$ Separate meetings were held during the annual spring meeting of the IMF and the Annual Meeting of the EBRD with

\footnotetext{
31 These commitments became part of the IMF agreements with the crisis countries. See for example the Concluding Statement of Participating Banks at the Financial Sector Coordination Meeting for Romania of 26 March 2009, available at http://www.imf.org/external/np/cm/2009/032609.htm (last visited 13 June 2011).

32 Interview with Vienna Initiative participants, on file with the author. The comparison with the crisis meetings on Greece's sovereign debt is striking. The Greek delegation did not partake in the closed-door meetings at which the rescue package was announced. See Nicholas Kulish and Steven Erlanger, "In Greek Pact, Compromises and Intrigues", The New York Times, 22 July 2011, A1, B4.

${ }^{33}$ See also Camilla Anderson, "Agreement with Banks Limits Crisis in Emerging Europe", IMF Online, October 2009, available at http://www.imf.org/external/pubs/ft/survey/so/2009/int102809a.htm (last visited, 31 May 2011).

${ }^{34}$ The financial contributions banks made to their subsidiaries in CEE over and above the financial support they received from their home governments is difficult to quantify. Still, these commitments compare well with the use of taxpayer moneys by banks elsewhere (Taliaverro, 2009).
} 
home and host country representatives to assess the implementation of the Vienna Initiative.

In September 2009, another full Vienna Initiative meeting was held in Brussels, this time under the chairmanship of John Berrigan, from the EU's Directorship General for Economic and Financial Affairs (DG ECOFIN). Seventeen parent bank groups, up from ten that had called for a European response to the crisis in November of 2008, their home and host country supervisors, and fiscal authorities participated, as did the IMF, the EC with representatives from the Directorate-General for Competition and CEBS, the EIB, the World Bank, the EBRD, and the ECB as observer. ${ }^{35}$ At the subsequent meeting in Athens in the spring of 2010, twenty bank groups and thirteen countries were represented (De Haas, Korniyenko, Loukoianova and Pivovarsky, 2011).

The Vienna Initiative succeeded in stabilizing the region by avoiding an uncoordinated withdrawal of capital from the region. Recent evidence suggests that subsidiaries of banks that participated in the Vienna Initiative maintained a larger credit portfolio than those that did not (de Haas et al. 2011). It prevented the socialization of debt by governments in the region, which would have most likely spurred a sovereign debt crisis along the lines of Ireland and Portugal. In addition, the Vienna Initiative laid the foundation for coordinated governance that has proved sufficiently resilient to survive the immediate period of crisis management. This does not mean that the Vienna Initiative achieved an equitable cost distribution. The concessions of banks and their home authorities notwithstanding, countries in CEE still bore the brunt of the crisis. Indeed, pressure from the EU and its member states ensured that countries that received IMF assistance had to comply with conventional structural adjustment programs (Lütz and Kranke, 2010). However, in comparison with other crises in emerging markets, but also with the crises in Ireland and Portugal, the outcome of the Vienna Initiative is remarkable.

The Vienna Initiative is often described as a unique ad hoc crisis resolution mechanism. De Haas et al. (2011) attribute its success to the fact that the number of creditor banks was relatively limited as compared to the East Asian financial crisis, for example. This dovetails with research on workouts of firms suggesting that the number of creditors is an important factor in the feasibility of a private workout rather than a formal bankruptcy proceeding (Gilson, et al., 1990). Yet, the total number of creditors may be less relevant than the ability to coordinate their action. The argument developed in this paper therefore stresses the importance of coordination and the attributes of the coordinating agent(s). A

\footnotetext{
${ }^{35}$ See "Largest Foreign Banks In Hungary Pledge Support To Local Units" with a summary of the concluding statement of the joint forum meeting held in Brussels on 24 September. Available at http://www.xpatloop.com/news/62975 (last visited 5 February 2011).
} 
critical factor for the success of the Vienna Initiative was the presence of an anchor tenant with a clear commitment to the region and the authority to bring together all critical stakeholders for resolving the crisis. More than one organization helped coordinate the Vienna Initiative, including the IMF, the EBRD, and the European Commission. However, it was the EBRD that spearheaded the regionalization of the crisis resolution. As discussed previously, the European Commission joined the process, but did so wholeheartedly only in the summer of 2009 after its success had already been established. The IMF had played a critical role in preventing a financial collapse in CEE through standby agreements since October 2008. Yet, these were not coordinated and instead followed the IMF's traditional bilateral, country-by-country approach. The important role the EBRD played in the Vienna Initiative can also be gauged from the management of the credit crises in Ireland and Portugal, which, unlike the crisis in CEE, was allowed to balloon into a sovereign debt crisis. In this crisis, both the IMF and the European Commission was involved, but neither made an attempt to create a coordinated workout at an early stage along the lines of the Vienna Initiative.

Identifying a potential anchor tenant for coordinating governance thus is a critical step in designing a governance regime for interdependent financial markets. This calls attention to the organizational features of agents that have proved to be capable of playing such a role, in this case the EBRD.

The EBRD is the youngest of the IFIs, which include the original Bretton Woods Institutions, the IMF and the World Bank, and its regional sister institutions for Africa, Asia and Latin America. It was established in 1990 with the mandate to support the transformation in the formerly socialist countries in CEE from centrally planned to market economies. As in the case of other IFIs, its equity holders are states as well as several international organizations. Unlike other IFIs, it is explicitly charged with working with and through the private sector. $^{36}$ The goal was to strengthen non-state actors and develop viable markets in transition economies, not to reform state socialism through state institutions. The EBRD's mandate is reflected in how it spends its money, the bulk of which is invested in private sector projects, often with co-funding from the private sector (EBRD, 2010). Success and failure of the projects are thus directly reflected in the EBRD's own financial statements. The EBRD's task to work directly with the

\footnotetext{
${ }^{36}$ Art. 1 of the Agreement specifically states that the EBRD's mandate is "to foster the transition towards open market-oriented economies and to promote private and entrepreneurial initiative in the Central and Eastern European countries committed to and applying the principles of multiparty democracy, pluralism and market economics." Art. 2 specifies as its functions the development of competitive private markets through "private and other interested investors" and the mobilization of domestic and foreign capital to promote these ends.
} 
private sector - in fact, it has substantial equity exposure to banks in the region ${ }^{37}$ - has placed it in much closer proximity to private actors than is usually the case for IFIs. ${ }^{38}$ This has situated the EBRD at the crossroads of private and public actors, with knowledge of and access to both, lending it credibility to bring both sides together, or to bridge the "structural hole" (Burt, 1995) that separates them by conventional approaches to regulation.

The internal organization and governance of the EBRD is also more conducive to flexible response strategies than those of the classic Bretton Woods Organizations. The latter are characterized by high levels of bureaucratization to ensure consistency and accountability (Barnett and Finnemore, 2004). These very features, however, make them less responsive to new challenges. In contrast, the organization of the EBRD is divided between investment operations that are subject to similar bureaucratic mechanisms, and a policy division headed by the office of the chief economist. The latter reports directly to the president of the bank. The fewer bureaucratic controls this organizational feature imposes means that the EBRD's policy arm can respond more flexibly to new challenges as they arise.

A potential disadvantage of the EBRD is that its resources are relatively limited. Its annual business volume on 2010 was $€ 9$ bln; the accumulated net volume $€ 62$ bln (up from 47.7 in 2009). Recent increases in business volume mostly in response to the crisis notwithstanding, this makes the EBRD a small player. On the positive side, a small budget limits the temptation to over-lend. ${ }^{39}$ Moreover, the EBRD's modest financial prowess has forced the bank to reach out to other IFIs and thereby broaden the scope of participants in the governance of a regional crisis.

The above account holds several lessons for identifying and designing anchor tenants for governing interdependent financial systems. An anchor tenant must have the trust and authority of relevant stakeholders, which needs to be built over time. In cases where diverse stakeholders are critical for sustaining a complex, interdependent system, the anchor tenant must build relations with all of them. Flexibility is critical so that it can respond to changes in a dynamic environment. Weberian bureaucracies with their emphasis on predictability and stability that dominate the world of international organizations (Barnett and Finnemore, 2004) are less suited for this task than are organizations with greater

\footnotetext{
${ }^{37}$ According to the 2011 financial report, at the end of 2010, 66.4 percent of total equity exposures was in banks (up from 61.7 percent), compared to only 13 percent in sovereigns. (EBRD, 2010).

${ }^{38}$ The IFC is a partial exception to this rule, but unlike the EBRD, it does not combine a broader developmental agenda with private sector initiatives.

${ }^{39}$ A strong argument can be made that multiplying the sources of finance is of critical importance when financing projects with uncertain outcomes. Having more than one creditor review a decision to extend financing at stage two of the project is an important commitment device against throwing 'good' money after 'bad' money. See (Huang and Xu, 2000).
} 
flexibility in their internal governance structure and in their relation to other stakeholders. Given the critical importance of private and public actors in today's interdependent financial systems, agents that are designed to interact exclusively with either government or private actors have a disadvantage. Last but not least, an anchor tenant must be able to engage diverse stakeholders while retaining its independence and credibility among all. This paradox appears to be easier resolved by lean organizations that need to persuade others about the merits of their undertaking than by behemoths that have the resources to dictate strategies.

\section{Outlook}

The Vienna Initiative emerged in the midst of the global crisis. It developed a novel strategy for managing a highly interdependent financial system in crisis. Its most important contribution has been the establishment of a private-public coordination platform with an anchor tenant at its core. If all the Vienna Initiative had done was to mitigate the impact of the global crisis in CEE, this alone would be deemed a success, but it would have hardly justified the claim it might evolve into a novel and sustainable governance regime for interdependent financial markets. Yet, this appears to be happening. Participants in the Vienna Initiative have launched a new phase, "Vienna Plus", which goes well beyond crisis management (EBRD, 2011). Specifically, the agenda for Vienna Plus calls for collaboration on regulatory issues among countries inside and outside of the European Union to take account of the actual reach of the pan-European financial market; it seeks to address issues of foreign currency-based lending, monitoring of the speed of credit growth, and a continued commitment to private/public coordination under the auspices of the EBRD.

"Vienna Plus" has maintained its only partially institutionalized form. The initiative is not housed anywhere and does not have a statute, management board or by-laws. It remains open to new participants and has retained its commitment to deliberation and publicity. Standard accounts that associate institutionalization with greater standardization of practices and eventual bureaucratization (Huntington, 1965) may dismiss this as unsustainable. In contrast, this paper has argued that coordinated governance is feasible and indeed necessary for governing financial interdependence. It has suggested that coordination can be achieved even when critical stakeholders have conflicting interests, as in this case host country governments, foreign banks and their home regulators. This, however, requires proactive coordination by a central agent. The paper has borrowed Powell's concept of the "anchor tenant" to suggest that international organizations may play a critical role as anchor tenant - provided they are designed to facilitate flexibility, responsiveness and independence. 
Pistor: Governing Interdependent Financial Systems

References:

Arcalean, Calin, Oscar Calvo-Gonzales, Csaba More, Adrian van Rixtel, Adalbert Winkler, and Tina Zumer, 2007, The Causes and Nature of the Rapid Growth of Bank Credit in the Central, Eastern and South-Eastern European Countries, in Charles Enoch, and Inci Ötker-Robe, eds.: Rapid Credit Growth in Central and Eastern Europe: Endless Boom or Early Warning? (Palgrave McMillan, New York).

Barnett, Michael N., and Martha Finnemore, 2004. Rules for the World: International Organizations in Global Politics (Cornell University Press, Ithaca).

Bednarski, Piotr, and Dariusz Starnowski, 2007, Home and Host Supervisors' Relations: A Host Supervisor's Perspective, in Charles Enoch, and Inci Ötker-Robe, eds.: Rapid Credit Growth in Central and Eastern Europe: Endless Boom or Early Warning? (Palgrave Macmillan, New York).

Berglöf, Erik, Yevgeniya Korniyenko, Alexander PLekhanov, and Jeromin Zettelmeyer, 2009, Understanding teh crisis in emerging Europe, EBRD Working Papers 2009.

Burt, Ronald, 1995. Structural Holes: The Social Structure of Competition (Harvard University Press).

Cetorelli, Nicola, and Linka S. Goldberg, 2011, Global Banks and International Shock Transmission: Evidence from the Crisis, IMF Economic Review 59, 41-76.

Claessens, Stijn, G.R. Underhil, and X Zhang, 2008, The political economy of Basle II: The costs for poor countries?, The World Economy 31, 313-344.

Coase, Ronald H., 1937, The Nature of the Firm, Economica 386-405.

Danielsson, Jon, Paul Embrechts, Charles Goodhart, Con Keating, Felix Muennich, Olivier Renault, and Hyun Song Shin, 2001, An Academic Response to Basel II, Special Paper LSE Financial Markets Group.

De Haas, Ralph, Yevgeniya Korniyenko, Elena Loukoianova, and Alexander Pivovarsky, 2011, Foreign Banks During the Crisis: Saints or Sinners?, ssrn.com.

De Haas, Ralph, and Iman Van Lelyveld, 2010, Internal Capital Markets and Lending by Multinational Bank Subsidiaries, Journal of Financial Intermediation 19, 1-25.

Dewatripont, Mathias, Gregory Nguyen, Peter Prait, and Andre Spapir, 2010, The role of State Aid Control in Improving Bank Resolution in Europe, Bruegel Policy Contribution 2010.

Dinger, Valeriya, 2009, Do Foreign-Owned Banks Affect Banking System Liquidity Risk?, Journal of Comparative Economics 37, 647--657.

EBRD, 2010, Financial Report, (EBRD, London). 
EBRD, 2011, Vienna Initiative - Moving to a New Phase, (European Bank for Reconstruction and Development, London).

EBRD, EIB, and WorldBank, 2011, Final Report on the Joint IFI Action Plan, (EBRD, London).

ECB, 2005. Banking Structure in the New EU Member States (European Central Bank).

Enoch, Charles, 2007, Credit Growth in Central and Eastern Europe, in Charles Enoch, and Inci Ötker-Robe, eds.: The Causes and Nature of the Rapid Growth of Bank Credit in the Central, Eastern and South-Eastern European Countries (Palgrave Macmillan, New York).

Fratianni, Michele, and John Pattison, 2002, International Financial Architecture and International Financial Standards, Annals, AAPSS 579, 183-199.

Gatzlaff, Dean H., Stacy C. Sirmans, and Barry A. Diskin, 1994, The Effect of Anchor Tenant Loss on Shopping Center Rents, Journal of Real Estate Research 9, 99-110.

Gelpern, Anna, 2004, Building a Better Seating Chart for Sovereing Restructurings, Emory Law Journal 53, 1115.

Gilson, Stuart C., John Kose, and Larry H.P. Lang, 1990, Troubled Debt Restructurings - An Empirical Study of Private Reorganization of Firms in Default, Journal of Financial Economics 27, 315-353.

Goodhart, Charles, and Dirk Schoenmaker, 2006, Burden sharing in a banking crisis in Europe, Swedish Riksbank Economic Review 2006, 34-57.

Herring, Richard J., 2007, Conflicts between Home \& Host Country Prudential Supervisors, Cross-Border Banking \& National Regulation (Chicago Federal Reserve).

Hilbers, Paul, Inci Ötker-Robe, and Ceyla Pazarbasioglu, 2007, Analysis of and Policy Responses to Rapid Credit Growth, in Charles Enoch, and Inci Ötker-Robe, eds.: Rapid Credit Growth in Central and Eastern Europe (Plagrave Macmillan, New York).

Howcroft, Nigel John, 2008, Universal vs. Territorial Models for Cross-Border Insolvency: The Theory, the Practice, and the Reality that Universalism Prevails, U.C. Davis Business Law Journal 8, 366.

Huang, Haizhou, and Chenggang $\mathrm{Xu}$, 2000, Financial Institutions, Financial Contagion, and Financial Crises, IMF Working Paper 2000.

Huntington, Samuel P., 1965, Political Development and Political Decay, World Politics 17.

IMF, 2003, International Standards: Strengthening Surveillance, Domestic, Institutions, and International Markets, (International Monetary Fund, Washington).

IMF, 2009, Global Financial Stability Report, (International Monetary Fund, Washington, DC). 
IMF, 2011, Regional Economic Outlook: Europe - Strengthening the Recovery, (International Monetary Fund, Washington, DC).

Kapstein, Ethan B., 1996. Governing the Global Economy: International Finance and the State (Harvard University Press, Cambridge, MA).

Kapstein, Ethan B., 2006, Architects of Stability? International Cooperation Among Financial Supervisors, BIS Working Papers.

Kindelberger, Charles, 2005. Mania, Panics, and Crashes: A History of Financial Crises (Wiley).

Krueger, Anne O., 2002. A New Approach to Sovereign Debt Restructuing (Internatinoal Monetary Fund, Washington, DC).

Lamfalussy, Alexandre, 2001, Final Report of the Committee of Wise Men on the Regulation of European Securities Markets, (European Union, Brussels).

Lane, Philip R., and Gian Maria Milesi-Ferritti, 2007, The External Wealth of Nationas Mark II: Revised and Extended Estimates of Foreign Assets and Liabilities, 1970-2004, Journal of International Economics 73, 223-250.

Lütz, Susanne, and Matthias Kranke, 2010, The European Rescue of the Washington Consensus? EU and IMF Lending to Central and Eastern European Countries, LEQS Paper 2010.

Mattli, Walter, and Ngaire Woods, 2009, In Whose Benefit? Explaining Regulatoroy Change in Global Politics, in Walter Mattli, and Ngaire Woods, eds.: The Politics of Global Regulation (Princeton University Press, Princeton).

Minsky, Hyman P., 1986. Stabilizing an Unstable Economy (Yale University Press, New Haven).

Moessner, Richhild, and William A. Allen, 2010, International liquidity provision and currency-specific liquidity shortages, BIS Working Paper.

Nitsche, Wolfgang, 2010, The Vienna Initiative/European Bank Coordination Initiative: Assessment and Outlook, Austrian Federal Ministry of Finance Working Paper Series 2010.

ONB, 2009, 1989-2009: Twenty Years of East-West Integration -- Hopes and Achievements, (Österreichische Nationalbank, Vienna).

ONB, 2009, Finanzmarkt-Stabilitätsbericht, (Österreichische Nationalbank (Austrian National Bank)).

Padgett, John F., and Paul D. McLean, 2006, Organizational Invention and Elite Transformation: The Birth of Partnership Systems in Renaissance Florence, American Journal of Sociology 11.

Pann, Johannes, Reinhardt Seliger, and Julia Übeleis, 2010, Foreign Currency Lending in Central, Eastern and Southeastern Europe: the Case of Austrian Banks, Finanzmarktstabilitätsbericht (ONB, Vienna). 
Payne, Anthony, 2010, How many Gs are thee in 'global governance' after the crisis? The perspectives of the 'marginal marjority" of the world's states, International Affairs 86, 729-740.

Pisani-Ferry, Jean, and Andre Sapir, 2010, Banking crisis management in the EU: an early assessment, Economic Policy 25, 341-373.

Pistor, Katharina, 2002, The Standardization of Law and Its Effect on Developing Economies, American Journal of Comparative Law 50, 101-134.

Pistor, Katharina, 2010, Host's Dilemma: Rethinking EU Banking Regulation in Light of the Global Crisis in Harald Baum, Brigitte Haar, Hanno Merkt, and Peter Mülbert, eds.: Festschrif für Klaus J. Hopt (de Gruyter, Berlin).

Pistor, Katharina, 2011, Into the Void: The Governance of Finance in Central and Eastern Europe, in Gerard Roland, ed.: Reflections on Transition: Twenty Years after the Fall of the Berlin Wall.

Pistor, Katharina, and Chenggang Xu, 2003, Incomplete Law, Journal of International Law and Politics 35, 931-1013.

Popov, Alexander, and Gregory F. Udell, 2010, Cross-border banking and the international transmission of financial distress during the crisis of 20072008, EBRD Working Paper Series 2010.

Powell, W.W., 1990, Neither market nor hierarchy: Network form of organization, Research in Organizational Behavior 12, 295-336.

Powell, Walter W., 2010, Organizational and Institutional Genesis and Change: The Emergence and Transformation of the Commercial Life Sciences, in John F. Padgett, and W.W. Powell, eds.: The Emergence of Organizations and Markets (Princeton University Press, Princeton).

Qian, Yingyi, Gerard Roland, and Chenggang $\mathrm{Xu}$, 2006, Coordination and Experimentation in M-Form and U-Form Organizations, Journal of Political Economy 114, 366-402.

Reinhart, Carmen, and Kenneth S. Rogoff, 2009. This Time is Different: Eight Centuries of Financial Folly (Princeton University Press, Princeton).

Roubini, Nouriel, 2001, Bail-ins, Bailouts, Burden Sharing and Private Sector Involvement in Crisis Resolution: some Suggestions on Open Unresolved Issues.

Ruggie, John G., 2004, Reconstituting the Global Public Domain - Issues, Actors, and Practices, European Journal of International Relations 10, 499-531.

Sabel, Charles, and Jonathan Zeitlin, 2008, Learning from Difference: The New Architecture of Experimentalist Governance in the European Union, European Law Journal 14, 271-327.

Simmons, Beth A., 2001, The International Politics of Harmonization: The Case of Capital Market Regulation, International Organization 55, 589-620.

Taliaverro, Ryan, 2009, How do Banks use Bailout Money? Optimal Capital Structure, New Equity, and the TARP, (ssrn.com). 
Tan, Celine, 2006, Review Essay: Reform or Reinvent: The IMF at a Crossroads, Global Governance 12, 507-522.

Vander Stichele, Myriam, 2008, Financial Regulation in the European Union: Mapping EU Decision Making Structures on Financial Regulation and Supervision.

Williamson, Oliver E., 1975. Markets and Hierarchies, Analysis and Antitrust Implications: A Study in the Economics of Internal Organization (Free Press, New York).

Woods, Ngaire, 2006. The Globalizers (Cornell University Press, Ithaca). 